\title{
Territorial Cohesion and Competitiveness in Tourism Development in Romania
}

\author{
Ionica SOARE ${ }^{\star}$, Florina Oana VIRLANUTA ${ }^{\star \star}$, Iulian Adrian SORCARU ${ }^{\star \star \star}$, \\ Ludmila Daniela MANEA ${ }^{\star \star \star \star}$, Mihaela-Carmen MUNTEAN ${ }^{\star \star \star \star \star}$, Rozalia NISTOR ${ }^{\star \star \star \star \star \star}$
}

\begin{tabular}{l}
\hline \multicolumn{1}{c}{ A R T I C L E I N F O } \\
\hline Article history: \\
Accepted December 2019 \\
Available online December 2019 \\
\hline JEL Classification \\
Z32, C25, C12 \\
Keywords: \\
Tourism, Competitiveness, \\
Romania, Territorial cohesion, \\
Development, Agritourism \\
\hline
\end{tabular}

\section{A B S T R A C T}

Substantial changes in the world economy, which have led to significant increases in the production of each country, but also in the reduction of political and trade barriers between countries, have caused, after 1970, an explosive development of tourism. The aim of the paper is to analyse the territorial cohesion and competitiveness in the tourism development in Romania.

(C) 2019 EAI. All rights reserved.

\section{Introduction}

Tourism, one of the most important sectors of the tertiary sector, together with the research and innovation ones, is also an economic and social phenomenon, a promoter of globalization and a factor of sustainable development.

Tourism has been evolving under the impact of changes in contemporary civilization, its dynamics being integrated into the general development process. By the magnitude of the human potential and the material that it encompasses in its development, as well as by the beneficial effects on the domains involved, tourism acts as a stimulating element of progress and development. Due to the numerous implications that it has from an economic, social, cultural and political point of view, due to its active role in society, on the one hand, and due to its transformations, on the other, the phenomenon of tourism must be known, in all its complexity, with all its weaknesses and incidents, so that its operating mechanisms could be fully comprehended.

At the beginning of the 21st century, tourism, under its various forms of manifestation, has undergone a marked development and diversification, being considered today as one of the most dynamic areas of the current economy. The main argument is the uninterrupted transformation, as a result of adapting the tourism phenomenon to the global economic demands of globalization, and the sustainable development of the tertiary sector. Tourism is an effect of the profound transformations that have taken place in the socioeconomic environment, namely the introduction of automation, the industrialization of agriculture, the modernization of the means of transport etc., all of which have determined the industrialization of the human society at a global level.

Currently, both economically developed and less developed countries have discovered the possibilities and prospects of this activity, considering it as an additional resource in balancing foreign exchanges and creating an image at a global level.

As part of the tertiary sector, tourism does not only contribute to GDP, but it also brings an important contribution to achieving added value. By its specificity - activity focused on providing services, high consumption of workforce, of intelligence and creativity - tourism participates in the creation of added value (VA) in a higher proportion than the branches which are close to its level of development.

We must also take into consideration the strong effect that tourism has on the production from other domains of activity, thus highlighting its synthesis and interference branch character. In this regard, we can emphasize the fact that the activity of some economic branches is determined by tourism needs, such as: the activity in hotels and restaurants, the cultural and recreational services, part of the transport activity, the travel and retail services, which are all generated by tourism. 
As a result, as far as the development and modernization of a country are concerned, tourism is also a means of diversifying its structure. The fulfilment of the requirements generated by the tourism activity favours, on the one hand, the emergence of specific branches (activities): the leisure industry, cable transport, travel agencies, handicraft production and, on the other hand, the emphasis of new dimensions regarding some existing branches: agriculture, food industry, construction, transport, cultural services.

Tourism can be considered an important "method" of capitalizing all categories of resources and, above all, the natural ones - others than the traditional ones - and/or small ones. For example, the beauty of the landscape, the curative qualities of mineral or thermal waters, climatic conditions, cultural and artistic events, art monuments, historical vestiges, folk tradition are best exploited by means of tourism. The exploitation of all these resources by means of international tourism generates an increase in income, a result of the lower (comparative) manufacturing costs on the domestic market as compared to those on the international one. At the same time, in relation to other branches of activity, which record economies of scale, tourism can also be developed through the exploitation of scattered small resources, being, from this point of view, an important component of local economies.

Due to these effects, tourism, as a branch of activity, is able to determine territorial transformations; from this point of view, it represents a means of mitigating inter-regional imbalances, at a national or world scale, a solution for the prosperity of the less-favoured areas or of the deindustrialised areas.

\section{State of the art}

The development of a certain geographical area is of tourist interest only insofar as the components of the natural and anthropic environment, by means of their quantitative and qualitative value, express possibilities for capitalization, thus giving some functionality to the territory together with the general and specific service network they attract, thus becoming important elements in land scaping plans.

Thus, the importance of estimating the tourism potential of a territory in Romania is highlighted and signalled by the domain-specific literature under various forms, even from the 1970s: by means of mathematical formulas that synthesize either briefly the attractiveness potential only of the physicogeographic and anthropic elements [1] or that comprise the tourism potential made up of only the technical elements or material resources. The literature also focuses on the basic criterion-based value index assignment model for the whole tourism potential - the natural, anthropic elements and the technical elements or material resources [2] or it relies on the ample presentation of the tourism potential element structure, volume and qualities, the intensity with which they are or can be attracted in the touristic circuit, the generated forms of tourism and tourism zoning [3, 4, 5, 6, 7]. Scores are also used in tourism potential assessment, in the sense of the "quantitative" assessment of the "quality" at the level of each category of elements per area at an institutional level (URBANPROIECT).

Recently, under the effects of tourism promotion and development policy, an assessment was performed on the basis of the methodology for distributing the score (maximum 25 points) at the level of a village or city for each category - natural tourism resources, anthropic tourism resources, specific tourism infrastructure and general infrastructure - by the domain-specific competent authorised institutions according to the structure of the tourism potential and to the infrastructure (tourism and general).

But both the size and the distribution of tourism potential and the degree of capitalization at the spatio-temporal level generate multiple approaches meant to anticipate an impact situation, to develop the territory or tourism phenomenon and/or to signal a risk such as: identifying existing and potential tourism attractions in rural areas and offer solutions to exploit them in order to make them attractive to tourists [8];tourism pressure in the context of sustainable development [9]; the need for Building-Related Indicators for the sustainable development of cities in order to ensure the sustainable and responsible use of tourism resources [10] etc.

More recently, approaches to tourism and infrastructure potential are a response to the major directions of the Territorial Cohesion concept [11] as a political objective at European level, namely the exploitation of territorial potential elements, the use of geographic characteristics in territorial development, the focus on three key strategic coordinates, namely the concentration of human activities, connecting cities and territories and real cooperation in various fields.

This concept draws attention to the knowledge of the territory to signal and recognize its diversity in the need to build in order to generate socio-economic development and, at the same time, underlies the creation of optimum conditions through policies so that each county can capitalize on its potential and increase the concentration of activities.

\section{Research methodology}

The multiple regression model is one of the most versatile and most commonly used statistical techniques used in economic analysis, and not only. Regression helps in determining the relation and is used especially in prediction studies.

The purpose of multiple regression (term used by Pearson, 1908) is to highlight the relationship between a dependent variable (explained, endogenous, and resultant) and a set of independent variables (explanatory, factorial, exogenous, predictors). Note that the multiple regression method is generalized by the theory of the "general linear pattern," in which multiple dependent variables as well as factorial variables, which are not linearly independent, are allowed simultaneously. 
in which:

$\boldsymbol{Y}=\boldsymbol{a}_{0}+\boldsymbol{a}_{1}{ }^{*} \boldsymbol{x}_{1}+\boldsymbol{a}_{2}{ }^{*} \mathrm{x}_{2}+\boldsymbol{a}_{3}{ }^{*} \mathrm{x}_{3}+\boldsymbol{e}_{1}$ (the equation of multiple linear regression)

$\mathbf{Y}=$ Overall tourism development potential score (resultative feature);

$\mathbf{x}_{\mathbf{1}}=$ Natural resources (factorial characteristic);

$\mathbf{x}_{2}=$ Anthropic resources (factorial characteristic);

$\mathbf{x}_{3}=$ Tourism specific infrastructure (factorial feature);

$\mathbf{e}_{\mathbf{1}}=$ residual variable;

$\mathbf{a}_{0}, \mathbf{a}_{1}, \mathbf{a}_{2}, \mathbf{a}_{3}=$ parameters of the regression function.

The linear regression method consists in determining a linear function of dependence of the form $\boldsymbol{f}(\boldsymbol{x})$ $=\boldsymbol{y}=\boldsymbol{a}+\boldsymbol{b} \boldsymbol{x}$, which approximates the calculation of the values $y$ by means of the values $x(y-$ is the dependent variable, $x$ - the independent variable or the predictor).

For this, the least squares method is used, which consists in minimizing the error square sum between the values $y_{i}$ and the values $f\left(x_{i}\right)$ calculated using the formula of the linear regression.

The least squares method (of the error) is the most common method of approximating a $\mathrm{y}=\mathrm{y}(\mathrm{x})$ dependence, under the form of a table (as in Table 1), by an analytical function called regression function (for the test proposed, polynomial function). Therefore, the least squares method is also called regression, with wide applicability in estimation, statistics, and data processing.

Table 1. Table of statistical data

\begin{tabular}{|c|c|c|c|c|c|}
\hline \multicolumn{2}{|c|}{$\begin{array}{l}\text { Division of counties by } \\
\text { development regions }\end{array}$} & $\begin{array}{l}\text { Natural } \\
\text { resources } \\
\text { (factor } x 1 \text { ) }\end{array}$ & $\begin{array}{l}\text { Anthropic } \\
\text { resources } \\
\left(\text { factor } x_{3}\right)\end{array}$ & $\begin{array}{l}\text { Tourist-specific } \\
\text { infrastructure } \\
\left(\text { factor } x_{2}\right)\end{array}$ & $\begin{array}{c}\text { Overall tourism potential } \\
\text { development score } \\
\text { (y result) }\end{array}$ \\
\hline \multirow{6}{*}{ N-E } & Botosani & 394.5 & 97.5 & 0.8 & $1,226.30$ \\
\hline & Iasi & 531 & 162 & 4.69 & $1,487.69$ \\
\hline & Neamt & 701.5 & 143 & 3.24 & $1,948.24$ \\
\hline & Suceava & 982.5 & 494 & 7.07 & $2,542.07$ \\
\hline & Vaslui & 420.5 & 488 & 0.42 & $1,250.42$ \\
\hline & Braila & 183 & 180 & 1.11 & 709.61 \\
\hline \multirow{4}{*}{ S-E } & Buzau & 469 & 59.5 & 2.53 & $1,615.03$ \\
\hline & Constanta & 539.5 & 297 & 38.46 & $1,872.46$ \\
\hline & Galati & 335.5 & 406 & 2.82 & $1,278.32$ \\
\hline & Tulcea & 554 & 295 & 3.75 & $1,299.75$ \\
\hline \multirow{9}{*}{$\mathrm{S}$} & Vrancea & 534.5 & 216 & 1.74 & $1,366.24$ \\
\hline & Arges & 841 & 198 & 3.99 & $2,453.97$ \\
\hline & Calarasi & 149 & 509 & 1.07 & $1,085.05$ \\
\hline & Dambovita & 526 & 132 & 5.05 & $1,756.05$ \\
\hline & Giurgiu & 249 & 341 & 0.22 & 775.72 \\
\hline & Ialomita & 196 & 94 & 2.97 & $1,017.97$ \\
\hline & Prahova & 436 & 143.5 & 0.62 & $1,411.62$ \\
\hline & Teleorman & 354 & 324 & 0.29 & $1,269.29$ \\
\hline & Dolj & 532.5 & 190 & 2.48 & $1,431.98$ \\
\hline \multirow{5}{*}{$S-V$} & Gorj & 530.5 & 163 & 2.92 & $1,655.42$ \\
\hline & Mehedinti & 563 & 372 & 1.16 & $1,305.16$ \\
\hline & Olt & 494 & 138 & 0.54 & $1,670.54$ \\
\hline & Valcea & 762 & 158.5 & 10.74 & $1,876.74$ \\
\hline & Bihor & 817 & 273 & 12.11 & $1,478.77$ \\
\hline \multirow{6}{*}{$\mathrm{N}-\mathrm{V}$} & $\begin{array}{l}\text { Bistrita- } \\
\text { Nasaud }\end{array}$ & 552 & 322 & 2.17 & $1,655.66$ \\
\hline & Cluj & 555.8 & 419 & 9.58 & $1,943.88$ \\
\hline & Maramures & 778.5 & 408 & 6.42 & $2,305.32$ \\
\hline & Satu-Mare & 360 & 744 & 1.78 & $1,243.78$ \\
\hline & Salaj & 406 & 186 & 0.62 & $1,336.12$ \\
\hline & Alba & 726.5 & 324 & 7.01 & $2,218.29$ \\
\hline \multirow{4}{*}{ CENTRU } & Brasov & 507.5 & 636 & 17.05 & $1,403.05$ \\
\hline & Covasna & 311.5 & 462 & 3.51 & $1,150.51$ \\
\hline & Harghita & 604 & 421 & 7.2 & $1,728.20$ \\
\hline & Mures & 734 & 370 & 5.06 & $2,804.06$ \\
\hline \multirow{6}{*}{ V } & Sibiu & 490 & 627 & 5.38 & $1,697.38$ \\
\hline & Arad & 491 & 573 & 6.14 & $1,787.14$ \\
\hline & Caras-Severin & 851.5 & 366 & 2.88 & $1,680.84$ \\
\hline & Hunedoara & 737.5 & 228 & 4.66 & $2,050.16$ \\
\hline & Timis & 535.5 & 429 & 8.09 & $1,815.09$ \\
\hline & Ilfov & 190.5 & 241 & 4.57 & 856.57 \\
\hline
\end{tabular}

The values resulting from calculations have been transposed into tables and graphical representations, including by means of mathematical modelling, to highlight issues through which one may 
infer the needs/priorities/intervention required at a local, regional and national level, which can afterwards be addressed by actors involved in the socio-economic and sustainable development of the administrativeterritorial units, such as:

* the behavior of each scoring category (natural tourism resources, anthropic tourism resources, specific tourism infrastructure, general infrastructure) in relation to another category and signaling trends at the county level in terms of the mathematical model;

* advantages and disadvantages in time and space resulting from the distribution of tourism potential elements and from the infrastructure;

* building a more realistic tourism profile, reflected by the concentration and dispersion of tourism potential elements based on its distribution;

* the identification of the areas that require promotion and development through sustainable tourism, in line with EU policy, especially of the rural ones, by encouraging agritourism as a form of tourism activity diversification;

* signaling the different possibilities of capitalizing on the existing tourism potential;

* maintaining the balance in tourism development at the county level in low-potential ATUs by introducing new opportunities.

\section{General statistics of the multiple regression equation}

Dispersion analysis, sometimes called analysis of variance (ANOVA - Analysis Of Variance), is one of the most pertinent statistical processing methods. The experiment method called ANOVA "scheduling/programming experiments" has proven its usefulness in obtaining quickly, and under advantageous conditions, the necessary information to substantiate managerial actions.

ANOVA is a set of methods for analysing observational data, which depend on several factors with concurrent action, with the aim of establishing the most important of them and of estimating their effects.

Data from the statistical table were processed and statistical procedures (interpolation) were applied to complete the statistical series to be tested.

Table 2. The correlation matrix

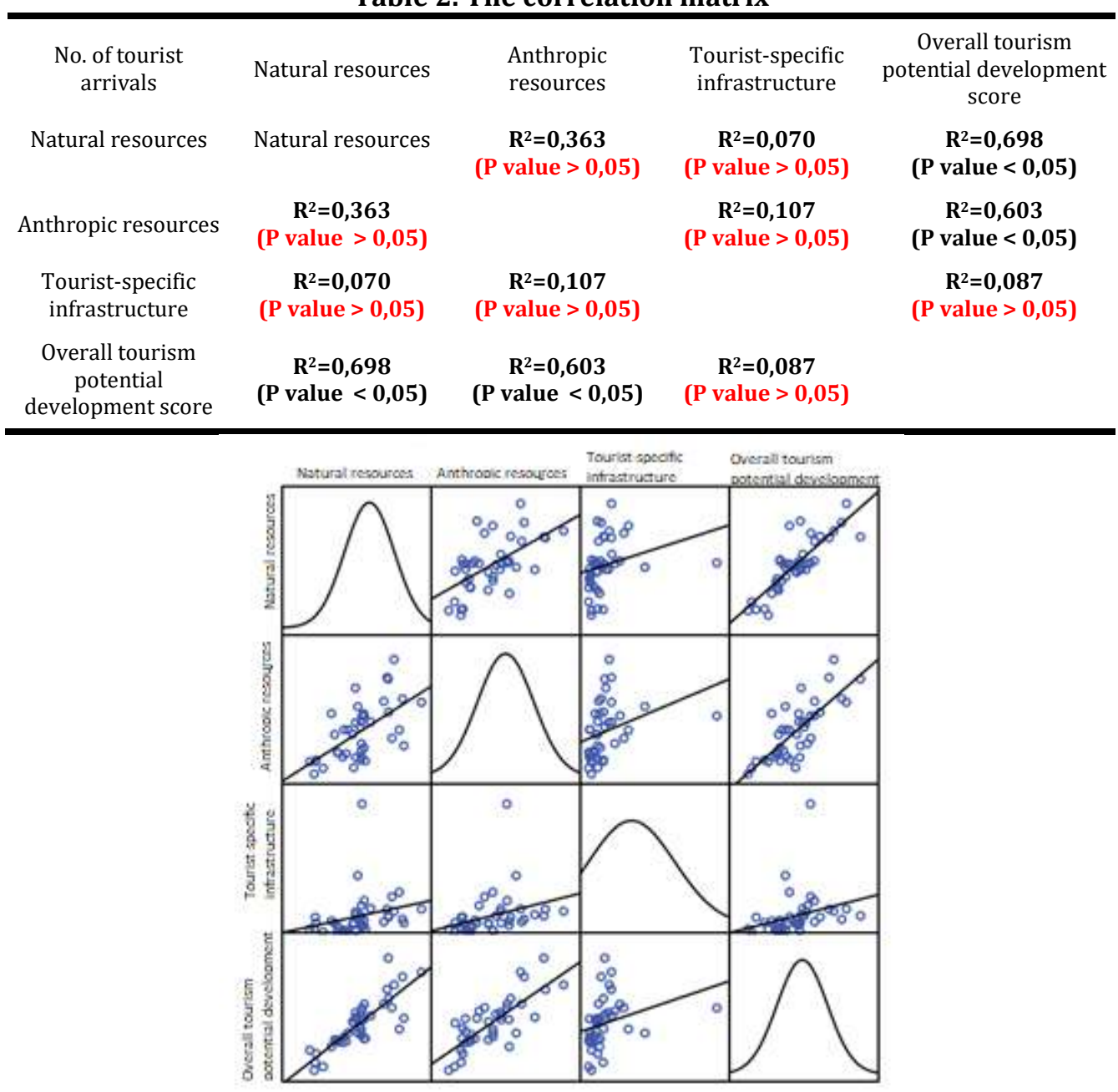

Figure 1. Scatterplot matrix 
The correlation can also be analysed by using a scatter matrix chart where the comparative development of the indicators are observed: natural resources, anthropic resources, tourism specific infrastructure, and overall potential tourism development score.

The intensity of the link between the variables by using the correlation ratio, testing its significance for a significance level of 0.05 is described in Figure no. 2.

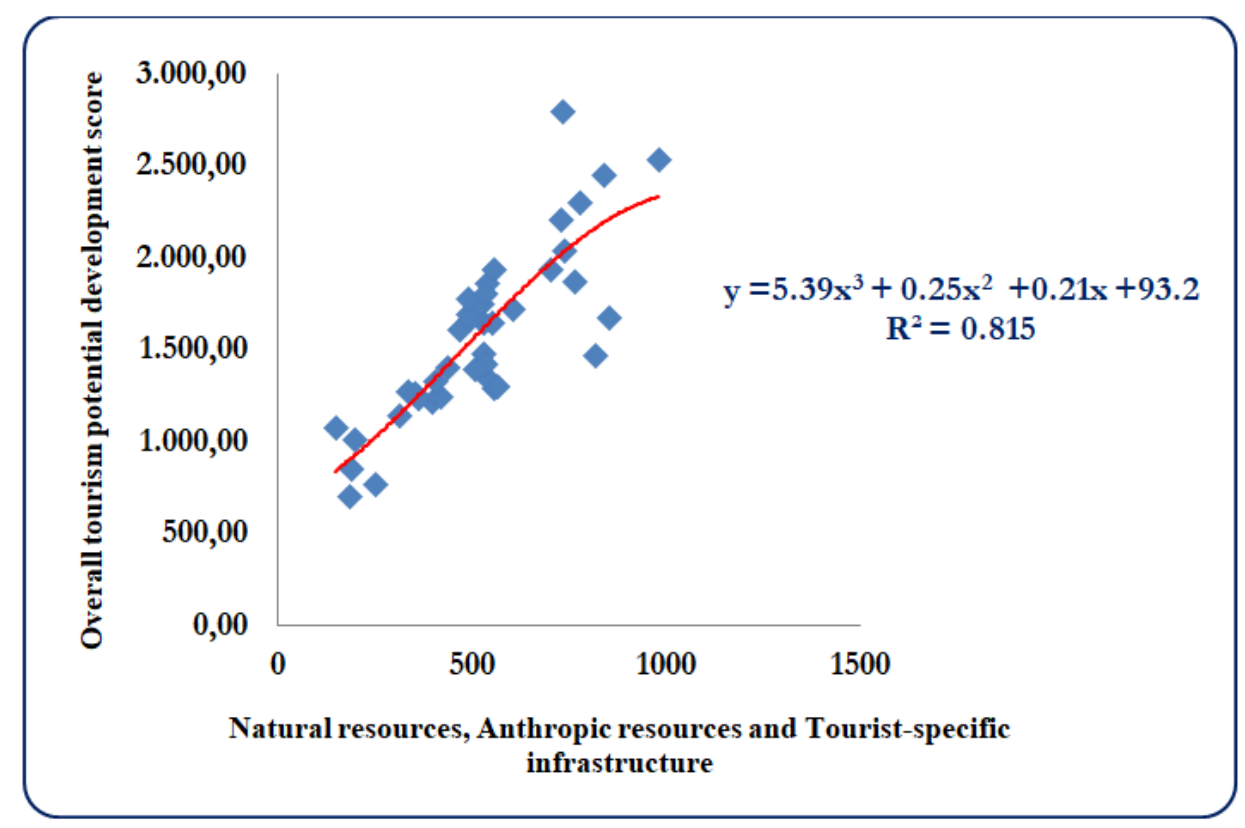

Figure 2. A third order polynomic model, used to determine the overall trend of the data series

One may easily notice that the indicators evolve according to similar trends, a fact that encourages the study of the correlation by using a software tool dedicated to IBM SPSS Statistics.

Table 3. ANOVA

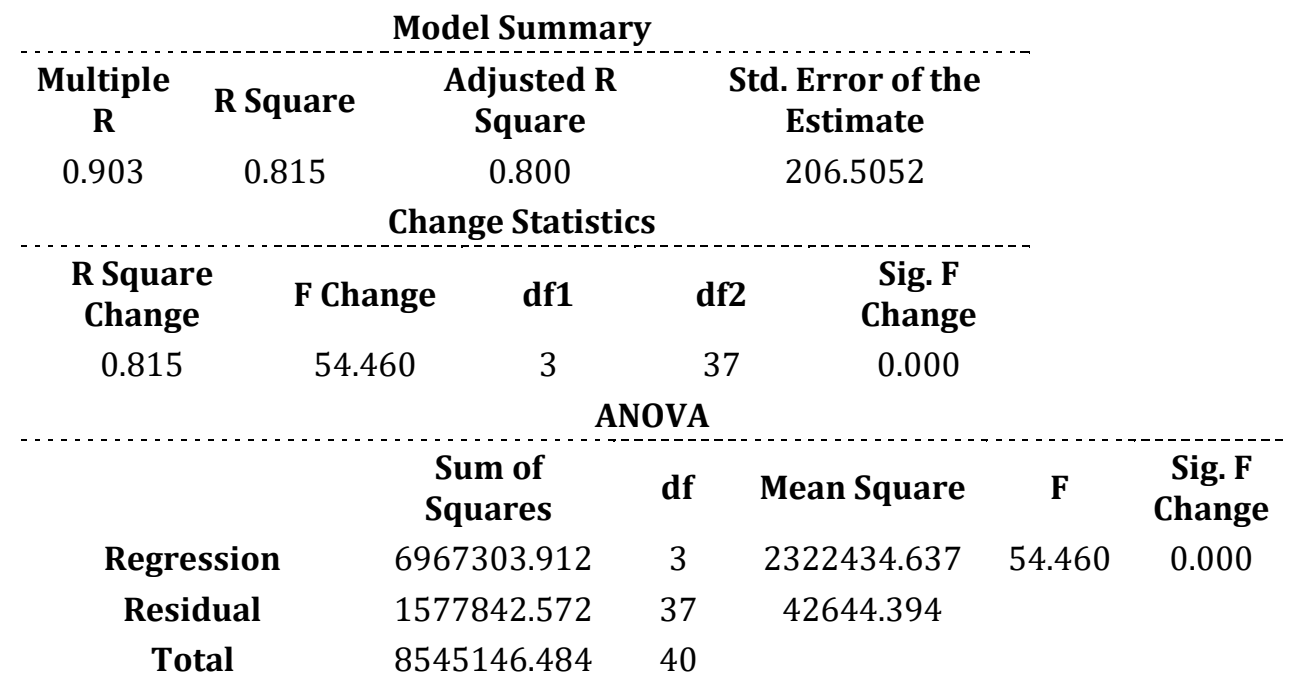

The coefficient of determination ( $R$ Square -) indicates the influence of the factors $\left(x_{1}, x_{2}, x_{3}\right)$ in the variation of the result $(y)$.

$\mathbf{R}$ Square $\mathbf{R}^{\mathbf{2}}=\mathbf{0 . 8 1 5}$ indicates that $\mathbf{8 1 . 5 \%}$ is the influence of the three factors on the variation of the overall score of tourism potential development.

In the table, we have Multiple $\mathbf{R}$ (the correlation ratio): $\mathbf{R}=\mathbf{0 . 9 0 3}$, which means that the link between the natural resources, the anthropic resources and the specific tourist infrastructure and the overall score of tourism potential development, respectively, is a strong one. 


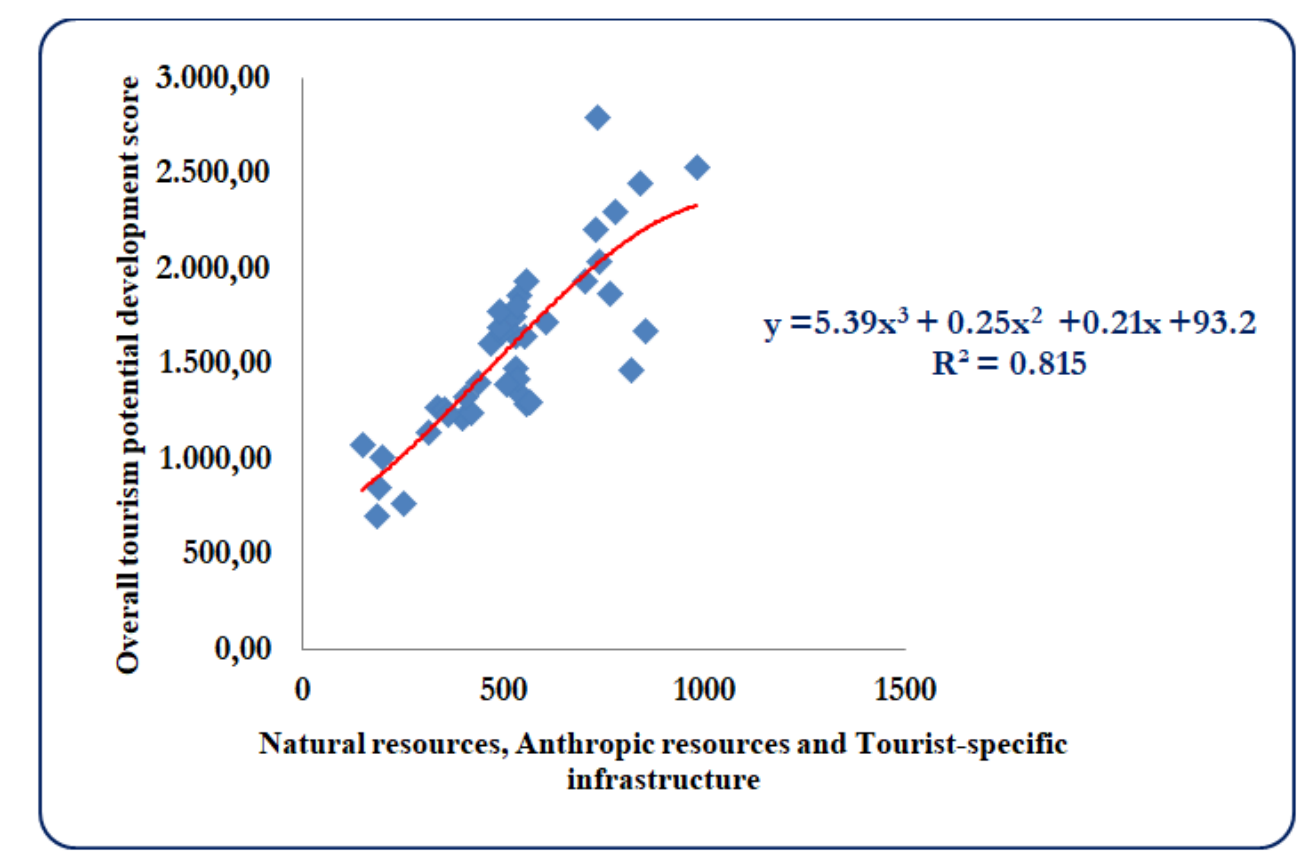

Figure 3. The polynomial model of the 3rd order regression equation to determine the general trend of the numerical series

By observing the graphical representation of the link between the overall score of tourism potential development and the natural resources, the anthropic resources and the tourism-specific infrastructure, one may advance the hypothesis that there is a direct link between the three variables: the more the independent variable increases (natural resources, anthropic resources and tourism-specific infrastructure) the more the dependent one (the total score for the development of tourism potential) increases. The points are distributed relatively evenly across the regression line.

\section{Regression model validation}

I. The null hypothesis $H_{0}: R=0$ (the correlation ratio of the collectivity does not differ significantly from zero, so it is not statistically significant);

II. The alternative hypothesis $H_{1}: R \neq 0$ (the correlation ratio of the collectivity differs significantly from zero, so it is statistically significant);

Knowing that the significance limit is $\alpha=0,05$ and that $\mathbf{k}=\mathbf{3}$ (there are three influence factors), we establish:

- The critical value:

$$
\mathrm{F}_{\text {tabelar }}=\mathrm{F}_{\alpha ; \mathrm{k} ; \mathrm{n}-\mathrm{k}-1}=\mathrm{F}_{\alpha ; 2 ; \mathrm{n}-3}=\mathrm{F}_{0,05 ; 3 ; 37}=2.85
$$

- The rejection region: if $\mathbf{F}_{\mathbf{c}}>\mathbf{F}_{\alpha ; \mathbf{k} ; \mathbf{n}-\mathbf{k}-1}$, then $\mathrm{H}_{0}$ is rejected.

Test statistic determination ( $F_{\text {calculat }}=F_{c}$ ) relies on the relation:

$$
\mathrm{F}_{\mathrm{c}}=\frac{\mathrm{R}^{2}}{1-\mathrm{R}^{2}} * \frac{\mathrm{n}-\mathrm{k}-1}{\mathrm{k}}=\frac{0.815352}{1-0.815352} * \frac{37}{3}=\frac{0.705403182}{0.2945968184330658} * 12.3=54.46
$$

Because $\mathrm{F}_{\mathrm{c}}(54.46)>\mathrm{F}_{0,05 ; 3,37}(2.85)$, then $H_{0}$ is rejected, therefore $H_{1}$ is accepted, which means that the correlation ratio of the collectivity from which the sample of 41 units was extracted differs significantly from zero, so it is statistically significant.

In order to build the regression function, we fill in the following table:

\begin{tabular}{|c|c|c|}
\hline & Coefficients & Coefficients \\
\hline Intercept (PT) & 507.512 & $b_{0}$ free term \\
\hline $\begin{array}{c}\text { Natural resources } \\
\text { (RN) }\end{array}$ & 1.358 & $\begin{array}{c}b_{1} \text { regression coefficient } \\
\text { (the first factor) }\end{array}$ \\
\hline
\end{tabular}




\begin{tabular}{|c|c|c|}
\hline $\begin{array}{c}\text { Anthropic resources } \\
\text { (RA) }\end{array}$ & 1.187 & $\begin{array}{c}b_{2} \text { regression coefficient } \\
\text { (the second factor) }\end{array}$ \\
\hline $\begin{array}{c}\text { Tourism-specific } \\
\text { infrastructure (IT) }\end{array}$ & 0.151 & $\begin{array}{c}\mathrm{b}_{3} \text { regression coefficient } \\
\text { (the third factor) }\end{array}$ \\
\hline
\end{tabular}

Therefore, the regression model is the following

$$
\hat{\mathrm{y}}_{\mathrm{x}_{1}, \mathrm{x}_{2}, \mathrm{x}_{3} \mathrm{i}}=507.512+1.358 * \mathrm{x}_{1 \mathrm{i}}+1.187 * \mathrm{x}_{2 \mathrm{i}}+0.151 * \mathrm{x}_{3 \mathrm{i}}
$$

Based on the data provided by IBM SPSS Statistics, we can write the regression model as follows:

$$
\mathrm{PT}=507.512+1.36 * \mathrm{RN}+1.19 * \mathrm{RA}+0,15 * \text { IT }
$$

The validity of the linear regression model for a significance level $\alpha=0.05$ is given in the table

\begin{tabular}{|c|c|c|c|c|c|}
\hline ANOVA & $\mathrm{df}$ (degrees of freedom) & $\begin{array}{c}\text { SS } \\
\text { (alternative/sum } \\
\text { of squares) }\end{array}$ & $\begin{array}{l}\text { MS (squares / } \\
\text { adjusted } \\
\text { dispersion) }\end{array}$ & $\mathrm{F}$ (calculated) & $\begin{array}{c}\text { Significance } \\
\text { F }\end{array}$ \\
\hline $\begin{array}{l}\text { Regression } \\
\text { (the } \\
\text { regression- } \\
\text { related } \\
\text { variation) }\end{array}$ & $\begin{array}{c}d f_{1}=k \\
\mathbf{3}\end{array}$ & $\begin{array}{c}\Delta_{y / x}^{2} \\
\mathbf{6 9 6 7 3 0 3 . 9 1 2}\end{array}$ & $\begin{array}{c}s_{y / x}^{2}=\frac{\Delta_{y / x}^{2}}{k} \\
2322434.637\end{array}$ & $\begin{array}{c}\text { The F test } \\
\mathbf{5 4 . 4 6 0} \\
\mathrm{F}=s_{y / x}^{2} / s_{e}^{2}\end{array}$ & $\begin{array}{c}1.2^{*} 10^{-13} \\
< \\
\alpha=0,05 \\
\left(\mathrm{H}_{0} \text { is }\right. \\
\text { rejected) } \\
\text { (The model } \\
\text { is valid) }\end{array}$ \\
\hline $\begin{array}{l}\text { Residual } \\
\text { (the } \\
\text { residual } \\
\text { variation) }\end{array}$ & $\begin{array}{c}d f_{1}=n-k-1 \\
\mathbf{3 7}\end{array}$ & $\begin{array}{c}\Delta_{e}^{2} \\
\mathbf{1 5 7 7 8 4 2 . 5 7 2}\end{array}$ & $\begin{array}{c}s_{e}^{2}=\frac{\Delta_{e}^{2}}{n-k-1} \\
\mathbf{4 2 6 4 4 . 3 9 4}\end{array}$ & & \\
\hline $\begin{array}{l}\text { Total (total } \\
\text { variation) }\end{array}$ & $\begin{array}{c}=\mathbf{d f}_{1}+\mathbf{d f}_{2} d f_{1}= \\
40\end{array}$ & $\begin{array}{c}\Delta_{\mathrm{y}}^{2}=\Delta_{\mathrm{y} / \mathrm{x}}+\Delta \\
\quad 8545146.484\end{array}$ & & & \\
\hline
\end{tabular}
below:

The significance of the regression model parameters for a significance level $\alpha=0.05$ is given in the

\begin{tabular}{|c|c|c|c|c|c|c|}
\hline ANOVA & $\begin{array}{c}\text { Coefficie } \\
\text { nts }\end{array}$ & $\begin{array}{l}\text { Standard } \\
\text { Error } \\
\text { (The } \\
\text { average } \\
\text { square } \\
\text { deviation) }\end{array}$ & $\begin{array}{l}t \text { Stat } \\
(\text { Test } t)\end{array}$ & P-value & $\begin{array}{c}\text { Lower 95\% } \\
\text { (The lower } \\
\text { limit of the } \\
\text { trust } \\
\text { interval) }\end{array}$ & $\begin{array}{c}\text { Upper } 95 \% \\
\text { (The upper } \\
\text { limit of the } \\
\text { trust } \\
\text { interval) }\end{array}$ \\
\hline Intercept & $\begin{array}{c}\mathbf{b}_{\mathbf{0}}= \\
507.512\end{array}$ & $\begin{array}{c}s_{b_{0}} \\
117.44113 \\
18\end{array}$ & $\begin{array}{c}t_{b 0}=\frac{b_{0}}{s_{b 0}} \\
4.71078139 \\
5\end{array}$ & $\begin{array}{l}3.4347 \\
9 * 10^{-5} \\
<0,05\end{array}$ & 318.6672 & 696.357 \\
\hline $\begin{array}{l}\text { Natural } \\
\text { resources }\end{array}$ & $\begin{array}{c}\mathbf{b}_{\mathbf{1}}= \\
1.358\end{array}$ & $\begin{array}{c}s_{b_{1}} \\
0.2176824 \\
44\end{array}$ & $\begin{array}{c}t_{b 1}=\frac{b_{1}}{s_{b 1}} \\
8.81325355 \\
5\end{array}$ & $\begin{array}{c}1.2764 \\
7^{*} \\
10^{-10} \\
<0,05\end{array}$ & 0.934425 & 1.781386 \\
\hline $\begin{array}{l}\text { Anthropic } \\
\text { resources }\end{array}$ & $\begin{array}{c}\mathbf{b}_{2}= \\
1.187\end{array}$ & $\begin{array}{c}s_{b 2} \\
0.2513960 \\
12\end{array}$ & $\begin{array}{l}t_{b 1}=\frac{b_{1}}{s_{b 1}} \\
7.694323\end{array}$ & $\begin{array}{l}2.43^{*} \\
10^{-9} \\
<0,05\end{array}$ & 0.677373 & 1.696126 \\
\hline $\begin{array}{l}\text { The tourism- } \\
\text { specific } \\
\text { infrastructur } \\
\text { e }\end{array}$ & $\begin{array}{c}\mathbf{b}_{3}= \\
0.151\end{array}$ & $\begin{array}{c}\mathrm{s}_{\mathrm{b3} 3} \\
6.6550049 \\
15\end{array}$ & $\begin{array}{c}t_{b 2}=\frac{b_{2}}{s_{b 2}} \\
0.87535627 \\
4\end{array}$ & $\begin{array}{c}0.3870 \\
27395 \\
>0,05\end{array}$ & -10.7786 & 11.08047 \\
\hline
\end{tabular}
table below: 


\section{Testing the statistical hypotheses}

The testing of a statistical hypothesis is done by comparing two competing hypotheses:

I. The null hypothesis - the model the researcher wishes to replace $\boldsymbol{H}_{\boldsymbol{0}}: \boldsymbol{\beta}_{0}=0$ (the $\beta_{0}$ slope is zero, i.e. $\beta_{0}$ is not significantly different from zero, so $\beta_{0}$ is not statistically significant)

II. The alternative hypothesis - the new model, meant to replace the null hypothesis $H_{1}: \beta_{0} \neq 0$, (the slope $\beta_{0}$ is not different from zero, i.e. $\beta_{0}$ is significantly different from zero, so $\beta_{0}$ is statistically significant)

Knowing that the significance limit is $\alpha=0,05$ and $\mathbf{k}=\mathbf{3}$ (there are three factors of influence) we establish:

- Critical value:

$$
\mathrm{t}_{\text {critic }}=\mathrm{t}_{\alpha ; \mathrm{n}-\mathrm{k}-1}=\mathrm{t}_{\alpha ; \mathrm{n}-4}=\mathrm{t}_{0,05 \text { BILATERAL; } \mathrm{n}-4}=\mathrm{t}_{0,05 \text { BILATERAL; } 37}=2.026
$$

- The rejection area: if $\left|\mathbf{t}_{\text {calc }}\right|>\mathbf{t}_{\alpha ; \mathbf{n}-4}$ sau $\left|\mathbf{t}_{\mathrm{b} \mathbf{0}}\right|>\mathbf{t}_{\alpha ; \mathrm{n}-4}$ then $\mathrm{H}_{0}$ is rejected;

\subsection{Testing the significance of the statistical parameter $\beta_{0}$}

The statistics of the test is: $\mathrm{t}_{\text {calc }}=\mathrm{t}_{\mathrm{b} 0}=\frac{\mathrm{b}_{0}}{\mathrm{~s}_{\mathrm{b} 0}}=\mathbf{5 . 4 4 5 3 0 1}$

One may notice that the parameter $\beta_{0}$ is statistically significant because:

- By comparing the test statistics to the critical test value (in a table form or theoretically) it follows that: $t_{b 0}(5.445301)>t_{\text {critic }}(2,026)$

- The critical limit P-value $\mathbf{b}_{\mathbf{0}}=\mathbf{3 . 5 4 0 7} * 10^{-6}<\alpha=\mathbf{0 , 0 5}$ (the significance limit);

- The lower range of the trust interval (lower $95 \%=318.6672)$ has the same sign as the upper limit of the range (upper $95 \%=696.357$ ).

\subsection{Testing the significance of the statistical parameter $\beta_{1}$}

The statistics of the test is: $t_{\text {calc }}=t_{b 1}=\frac{b_{1}}{s_{b 1}}==6.49706$

One may notice that the parameter $\beta_{1}$ is statistically significant because:

- By comparing the test statistics to the critical test value (in a table form or theoretically) it follows that: $\mathrm{t}_{\mathrm{c}}\left(\mathbf{6 . 4 9 7 0 6 )}>\mathrm{t}_{\text {critic }}(2,026)\right.$;

- The critical limit P-value $\beta_{1}=\mathbf{1 . 3 3 7 9} * 10^{-7}<\alpha=\mathbf{0 , 0 5}$ (the significance limit);

- The lower range of the trust interval (lower $95 \%=0.934425$ ) has the same sign as the upper limit of the range (upper $95 \%=1.781386$ ).

\subsection{Testing the significance of the statistical parameter $\beta_{2}$}

The statistics of the test is: $t_{\text {calc }}=t_{b_{2} 2}=\frac{b_{2}}{s_{b 2}}=4.720638$

One may notice that the parameter $\beta_{2}$ is statistically significant because:

- By comparing the test statistics to the critical test value (in a table form or theoretically) it follows that: $\mathbf{t}_{\mathrm{c}}(4.720638)>\mathbf{t}_{\text {critic }}(2,026)$;

- The critical limit $P$-value $b_{2}=3.3326 * 10^{-5}>\alpha=0,05$;

- The lower range of the trust interval (lower $95 \%=0.677373$ ) has the same sign as the upper limit of the range (upper $95 \%=1.696126$ ). 


\subsection{Testing the significance of the statistical parameter $\beta_{3}$}

The statistics of the test is: $\mathbf{t}_{\text {calc }}=\mathbf{t}_{\mathrm{b} 3}=\frac{\mathbf{b}_{3}}{\mathbf{s}_{\mathrm{b} 3}}=\mathbf{0 . 0 2 7 9 7 8}$

One may notice that the parameter $\beta_{3}$ is not statistically significant because:

- By comparing the test statistics to the critical test value (in a table form or theoretically) it follows that:

$$
-\mathrm{t}_{\text {critic }}(-2,026)<\mathrm{t}_{\mathrm{b} 3}(0.027978)<\mathrm{t}_{\text {critic }}(2,026)
$$

- The critical limit $\boldsymbol{P}$-value $\boldsymbol{b}_{3}=0.977829827>\alpha=0,05$;

- The lower range of the trust interval (lower $95 \%=-10.7786$ ) has the opposite sign as compared to the upper limit of the range (upper $95 \%=+11.08047$ ).

For the endogenous variable (the resultant) - the overall tourism development potential, the following graph will be created, with the following values predicted on the $\mathbf{0 x}$ axis and the following residual values predicted on the $\mathbf{O y}$ axis. The red lines are used for the graphical representation of the above-mentioned interval, between which the residual values must be comprised, in order to accept the normality hypothesis

Figure 4. The graphical representation of the proposed range on the significance limit $0.05 \%$

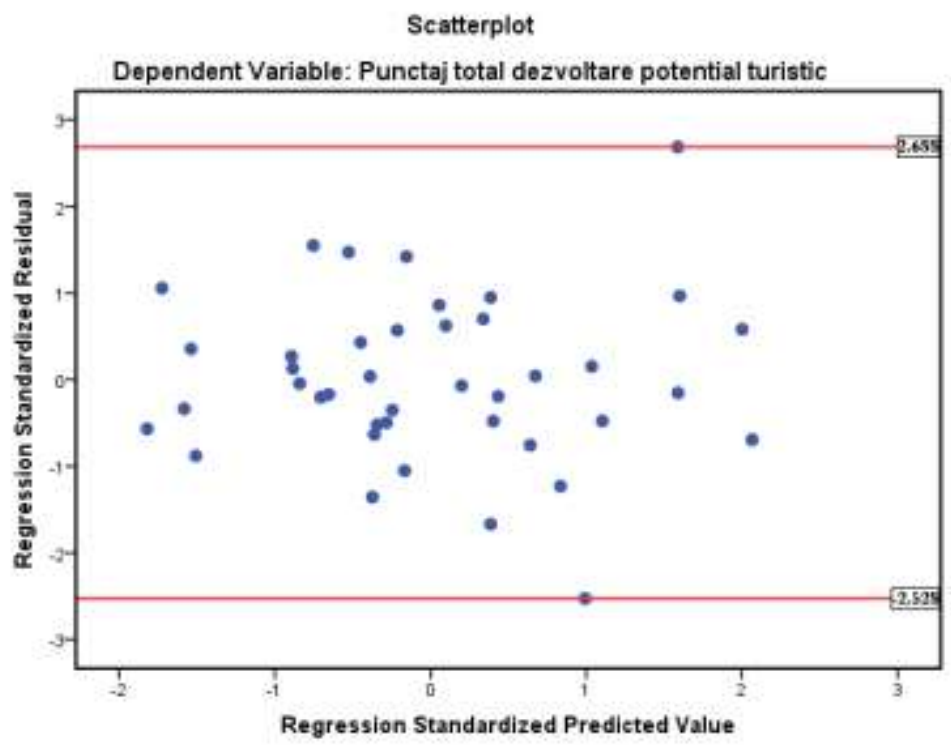

It is noted that there are values outside the acceptance range of the normality hypothesis, fact which demonstrates the existence of sufficient statistical evidence to reject the null hypothesis in favour of the alternative one: error distribution is not normal in the analysed situation.

\section{Conclusions}

The ANOVA method, used in this paper and implemented by using the dedicated software IBM SPSS Statistics, allows the identification of the independent variable influence, also called "experimental factors", on the dependent variable, and the "manipulation" of the variable values applies only to them.

The estimated multiple regression model proved to be accurate - a high determinant coefficient of $\mathbf{R}^{2}=\mathbf{0 . 8 1 5}$, i. e. the overall value of the tourism potential development score is explained by $81 \%$ of the independent variables included in the model.

In addition, the least squares assumptions (MCMMP) are perfectly verifiable - errors are homoscedastic, they are not auto correlated, and the variables are not collinear. The value of the $\mathbf{F}$ test (4.460) is large enough to determine the overall validity of the model for a significance limit Significance $\mathbf{F}=$ $1.2^{*} 10^{-13}$, much lower than $\alpha=0.05$.

The tourism potential and infrastructure assessment of the territorial-administrative units (county, village, city), obtained on the basis of the differences within and outside the less favoured areas of the same county, provides an overview of Romania's level regarding the following aspects:

- identifying areas/territories that require intervention: in the development of economic activities by means of tourism making the most of the local (natural and anthropic) heritage, by means of innovative actions, in order to increase attractiveness through tourism, especially in rural areas (both for the population and for 
tourists), so that the local population could identify themselves with the respective area, this leading to a decrease in emigration towards urban areas;

- in sustainable development, especially of the rural, less favoured areas that are threatened by the activity abandonment phenomenon, which can affect both the viability of rural areas and the local environmental factors (biodiversity, soil or landscapes), where the continuation of agricultural activity holds an important role in the preservation of traditional landscapes, which can serve as a basis for economic development, including through tourism;

- explaining/justifying the different opportunities and needs for developing and diversifying the forms/types of tourism, as well as their promotion: the development of rural tourism where the concentration of the tourism attraction elements and the high score are emphasized at the village level, because, as it has already been mentioned in the "National Rural Development Program for the period 2014-20120", the rural, ethnofolklore, gastronomic traditions and local environmental characteristics are insufficiently exploited as far as tourism development is concerned in order to create jobs, generate income and ensure a positive impact on the sense of dignity and pride of local communities;

- the introduction and development of other types of activities than those involving little or no elements that have been the subject of tourism potential assessment (such as gastronomy and gourmet tourism, agrotourism, the event or festival-based tourism etc.) in counties with basic administrative-territorial units (villages and cities);

- the introduction and development of those types of activities strictly related to sustainable tourism, directly linked to the location of villages and cities in less favoured areas, such as agritourism in rural areas building a realistic tourism profile at the county level by signalling the presence and distribution of tourism potential elements.

\section{References}

1. Iordan I, Niculescu E, O metodă de determinare sa potențialului turistic, Lucrările celui de-al II-lea Colocviu național de geografie a turismului, Editura Sport-Turism, Bucuresti, 1975

2. Cocean Pompei, Geografia turismului, Editura Carro, București, 1996

3. Cândea Melinda, Erdeli George, Simon Tamara, Potentialul turistic și turism, Editura Universității, Bucuresti , 2000

4. Cândea Melinda, Erdeli George, Simon Tamara, Peptenatu Daniel, Potenţialul turistic al României şi amenajarea turistică a spaţiului, Editura Universitară, București, 2003.

5. Ielenicz Mihai, Comănescu Laura, România·Potenţial turistic, Editura Universitară, Bucureşti, 2006.

6. Muntele Ionel, Iaţu Corneliu, Geografia turismului·concepte, metode şi forme de manifestare spaţio-temporară, ediţia a II- a revăzută, Editura Sedcom Libris, Iaşi, 2006.

7. Soare Ionica, Turism - tipologii și destinații, Editura Transversal, 2007

8. Trukhachev, A. Methodology for Evaluating the Rural Tourism Potentials: A Tool to Ensure Sustainable Development of Rural Settlements. Sustainability 2015, 7, 3052-3070.

9. Gogonea, R.-M.; Baltălungă, A.A.; Nedelcu, A.; Dumitrescu, D. Tourism Pressure at the Regional Level in the Context of Sustainable Development in Romania. Sustainability 2017, 9, 698.

10. Lerario, A.; Di Turi, S. Sustainable Urban Tourism: Reflections on the Need for Building-Related Indicators. Sustainability 2018, 10,1981

11. https://www.fonduri-structurale.ro/Document_Files/Stiri/00017493/7hctm_Anexe.pdf 